\title{
AN ASSESSMENT OF AVIATION SAFETY MANAGEMENT SYSTEM APPLICATIONS FROM THE NEW INSTITUTIONAL THEORY PERSPECTIVE*
}

\author{
Res. Asst. Yeşim KURT \\ Anadolu University, Faculty of Aeronautics and Astronautics, Eskişehir, Turkey (yesimkurt@anadolu.edu.tr) \\ Assoc. Prof. Dr. Ender GEREDE** \\ Anadolu University, Faculty of Aeronautics and Astronautics, Eskişehir, Turkey (egerede@anadolu.edu.tr)
}

\begin{abstract}
The Safety Management System (SMS) is a new management practice used in addition to the current prescriptive regulatory approaches. This study aims to find out, from the perspective of the new institutional theory, the diffusion of the SMS among the aviation organizations. Deductive and inductive methods were used together for the analyses of the qualitative data. The research shows that what lies beneath the diffusion of SMS is regulative institutional pressure, and that the field is dominated by coercive isomorphism mechanisms and a concern for legitimacy. Furthermore, it is found that the majority of organizations that participated in this study had recourse to decoupling strategies in SMS and adopted SMS practices only in a ceremonial way.
\end{abstract}

Keywords: New Institutional Theory, Aviation Safety Management System, Diffusion, Strategic Responses

\section{YENI KURUMSAL KURAM PERSPEKTIFIYLE HAVACILIKTA EMNIYET YÖNETIM SISTEMI UYGULAMALARININ DEĞERLENDİILMESI}

\section{ÖZET}

Emniyet Yönetim Sistemi (EYS), mevcut düzenleyici yaklaşıma ek olarak geliştirilen yeni bir yönetim uygulamasıdır. Bu çalışma, yeni kurumsal kuram perspektifinden, EYS'nin havacılık örgütleri arasındaki yayılımını açıklamayı amaçlamaktadır. Araştırmadaki nitel veriler, tümdengelimsel ve tümavarımsal yöntemler birlikte kullantlarak analiz edilmiştir. Araştırma sonucunda, EYS'nin yayılımının kuralcı kurumsal baskılara dayandı $\breve{g}$, alanda zorlayıcı eşbiçimlilik mekanizmasının ve meşruiyet kaygısının hâkim olduğu sonucuna ulaşılmıştır. Ayrıca, araştırmaya katılan örgütlerin çoğunun EYS için ayırma stratejisi

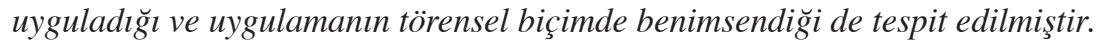

Anahtar Kelimeler: Yeni Kurumsal Kuram, Havacılık Emniyeti Yönetim Sistemi, Yayılım, Stratejik Tepkiler.

\footnotetext{
* This study is based on the Master's thesis of the first author under the supervision of the second author

** Corresponding Author
} 


\section{Introduction}

Air transportation, growing fast through the influence of globalization and technological advances, provides rapid and comfortable transportation services. It is important that air transportation is safe and secure (ICAO, 2006:1-2; 2009:3-5) as much as it is rapid and comfortable. International regulatory and auditory civil aviation authorities have adopted various regulations to improve safety over many years. Although air transportation is a safe mode of transport and the rate of accidents has reduced over the years, accidents still constitute a factor that compromises the system and attracts attention because of the ongoing growth of air traffic. In this respect, in the early 2000s, the International Civil Aviation Organization (ICAO) noted that it would not be enough to comply with safety regulations to improve safety, and adopted a performance-based approach and Safety Management System, which is differs from systems implemented in the past (Wiegmann \& Shappel, 2003:8-9; ICAO, 2003:67; Transportation Research Board, 2009:7). The civil aviation authorities have significant expectations from the SMS for safety improvement. This is why it is highly important for the improvement of aviation safety that SMS, spreading rapidly among aviation organizations through the support of international civil aviation authorities, is fully adopted and put into practice by organizations. The question is which institutional pressure has forced aviation organizations to implement this system rapidly, and whether they adopted the system because they think it is effective and efficient or for other reasons.

The new institutional theory is likely to provide an answer to this question. The theory, which explains the process of diffusion and adoption in the literature, is appropriate for this study. The main aim of this study is to investigate the implementation of the SMS in aviation organizations from the perspective of the new institutional theory. The study sets out to comprehend the assumptions of this theory on the basis of the SMS practices, and seeks answers to the following research questions in order to achieve its aim:

1. What are the factors that govern the diffusion of Safety Management System?

2. What are the strategic responses that aviation organizations have adopted in the face of institutional pressure related to Safety Management System?

3. Is Safety Management System being adopted in a ceremonial or in a rational way?

\section{Literature Review}

\subsection{The New Institutional Theory}

The focus of the new institutional theory, developed in the 1970s, is not a single organization, but a network formed by organizations (Greenwood \& Hinings, 1996). The main thesis of this theory is related to the adaptation of organizations into the institutional environment in which they are located. According to new institutional theorists, organizations adapt to their technical environment to provide efficiency, on the one hand; on the another hand, they also adopt the institutions offered by the environment to establish legitimacy within their institutional environment, even at the risk of reducing their technical efficiency, on the other hand (Meyer \& Rowan, 1977; Dimaggio \& Powell, 1983). 
The theory essentially seeks an answer to the question "what makes organizations so similar to each other? DiMaggio \& Powell (1991) suggests that "the organizations operating in the same organizational field adapt to the institutional environment and become similar to each other in order to gain legitimacy'. This causes isomorphism in the institutional environment. The new institutional theory, where the level of analysis is macro, puts emphasis on the institutional environment, where organizations strive to become legitimate to survive. Suchman (1995) and Parsons (1956) define legitimacy as 'complying with beliefs and values of the social system.' Legitimacy is seen as one of the main requirements for an organization to survive (Parsons, 1960; Pfeffer \& Salancik, 1978). This is why, the new institutional theorists suggest that organizations strive to gain legitimacy consciously or unconsciously. The main reason for this is that legitimacy increases the survival chance of organizations (Meyer \& Rowan, 1977).

Suhcman (1995) defines three types of legitimacy: Cognitive legitimacy occurs when organizations earn a 'taken-for-granted' status that is unquestionable and beyond dissent; moral legitimacy is related to compliance with the moral value judgments of society; and finally, pragmatic legitimacy is related to compliance with rational interests and rules (Özen, 2013:126). One of the main assumptions of the theory is that organizations in the same organizational field become isomorphic because of coercive, normative and mimetic mechanisms (DiMaggio \& Powell, 1991:67). Coercive isomorphism is related to pressure arising from tools, such as laws and regulations, introduced by the state, or dependence on actors for resources of the organization (Özen, 2013:128; DiMaggio \& Powell, 1991), while normative isomorphism is associated with professionalization. In the latter, social and cognitive bases of organizational structure become a standard, through which organizations gain legitimacy and survive (Morrill \& Mckee, 1993:449-456). Mimetic isomorphism is a result of organizations' efforts to imitate other organizations which, they believe, are more successful (DiMaggio \& Powell, 1991).

In early studies based on the theory, there was a great focus on structural compliance with the institutional environment and isomorphism. In this respect, Oliver (1991) argues that the organizational behavior that causes different types of responses were disregarded. Oliver suggests that organizations develop five different strategies in the face of pressure in the institutional environment; acquiesce, compromise, avoidance, defiance and manipulation. The factors that direct organizations to choose one of these five strategies, listed from passive to active and each including three different responses, are dependent on the source of institutional pressure, legitimacy to be gained and benefits of conformity (Oliver, 1991:151-160). In avoidance strategy, also defined by Pfeffer and Salancik (1978), there may be three responses; concealing, buffering and escaping. The avoidance strategy brings to mind decoupling, which is a concept emphasized in the new institutional theory.

Institutional actors, who produce new structures and ensure the survival of entities, have an important place in the new institutional theory (Scott et al., 2000; Meyer, 2008). Since the state has authority over other organizations, it has a more privileged position among actors (DiMaggio \& Powell, 1991). For, the state has privileged sources of power, such as distribution of resources, imposition of taxes or auditing other organizations. It is considerably recognized in the new institutional theory that the state leads to institutional change because of the power it holds; however, it is also underlined in the theory that change has not always been adopted easily (Vermeulen et al., 2007:532). The innovations in the organizational field are used, in 
some cases, for rational purposes to seek effectiveness and efficiency. Yet, in other cases, these practices have legendary characteristics and no technical efficiency, and are performed for the purpose of legitimacy or just because others perform them. At this point, the important factors are when an innovation is adopted, the type of decision-making for implementation and the method of implementation. Those adopting this practice for the first time, for the purpose of efficiency, have rational approaches, and those adopting the practice afterwards for the purpose of legitimacy have ceremonial approaches. The indicators of ceremonial adoption are defined as making a decision blindly and adopting without conducting a cost-benefit analysis, as others do, without adapting it to the organization (Tolbert \& Zucker, 1983; Meyer \& Rowan, 1977; Westphal et al., 1997; Armour \& Teece, 1978).

The concept of decoupling that emerged as a solution to the conflict between a technical and an institutional environment is important in that it indicates whether a practice is adopted in real terms (Meyer \& Rowan, 1977). Organizations strive to reduce costs and increase effectiveness and efficiency on the one hand, and seek acceptance in their institutional environment on the other hand. Aspiring to satisfy the institutional environment and not to lose technical efficiency at the same time, organizations oscillate between the two environments and are faced with conflict. In such cases, organizations may fail to incorporate a new practice into their internal processes because of technical concerns, prefering to give an external impression that they adopted the practice by assuring compliance on paper. At this point, what indicates the presence of decoupling are the adoption of steps that are easy to implement and which do not require structural change in the organization, avoidance of practices that require radical changes in the organization, and limited participation of employees in the practice (Özen, 2002:78). In the case of decoupling, there is a discrepancy between formal structure and organizational procedures of organizations, whit audit valuation processes becoming ceremonial, and there is an effort to prevent conflict between units and uncertainties. The organization moves away from formal procedures and starts placing more importance on human relation (Erel, 2002:7475).

\subsection{Safety Management System}

There has been a paradigm shift in safety management approaches in recent years. Aware that safety cannot be improved further by adopting only a normative and regulatory compliance-based approach, a deterministic management approach that sees the world as it should be, the ICAO has sought new approaches (ICAO, 2006:1-6; 2009:3-13). The SMS is the product of a paradigm shift from seeing the world as it should be to how it really is. There has been a shift from a regulatory compliance-based approach to a performance based approach; from reactive to proactive tools. The performance-based approach suggests that people or organizations are likely to make errors or violations even when they comply with regulations (FAA, 2004:25), and that this may create unsafe situations (Transportation Research Board, 2009:7). It is argued that aviation safety focuses on increasingly complex regulations and that these prescriptive regulations fail to reflect daily practices (Maher et al., 2013:2), and that a performance-based safety management approach is likely to fill this gap in safety practices. Thus, safety performance will be improved under real-life conditions (Gerede, 2015a; Gerede, 2015b). 
The SMS is a management tool developed by international authorities in the aviation industry. Because of the nature of their operations, aviation organizations are required to ensure safety. This is why it is considered that there are aviation organizations in the sector which adopt this approach, not only because of obligation, but also from a rational perspective. It is very important for organizations to adopt, find useful and implement these systems as expected in order to ensure that such endeavors for the improvement of safety achieve their goal. However, it is also assumed that organizations may not yet have comprehended the benefits of Safety Management System and how to implement it, as it is a product of a paradigm shift and a brand new approach. The factors that are likely to affect the success of the SMS and its contribution to the improvement of safety are whether these organizations have put the SMS into practice, why they have adopted the SMS, whether the SMS is adopted because they regard it as an effective and beneficial approach or because they wanted to conform to authorities' expectations, and whether the SMS is adopted in a rational way.

The framework of the SMS, designed by the ICAO, comprises four main components, including a total of twelve items (ICAO, 2006: 7-App 2-2; ICAO, 2009: 8-3; 2013a: 5-2). The ICAO requires the organizations that implement the SMS to adopt a four-step approach, each taking six months (ICAO, 2009:10-1, 2013a:4-14), and charges member states with the responsibility of launching and implementing the State Safety Programme, and to ensure that service providers implement the SMS and control its implementation (ICAO, 2009:6-2; 2013b: 3-1). In this respect, the Turkish Directorate General of Civil Aviation (DGCA), a party to the ICAO, adopted a model consisting of four main components and twelve items designed by the ICAO and required service providers throughout the country to implement, the SMS according to this model (DGCA, 2011; 2012a; 2012b; 2012c). The DGCA has obliged aviation organizations in Turkey to implement the SMS from 2012. As the public authority that governs the process, the DGCA is the only authority that constitutes the basis for the diffusion of the SMS in Turkey. With the process starting in 2012, aviation organizations throughout Turkey launched the SMS, and as from 2013, they were expected to have completed the transition process and to be implementing the SMS.

\subsection{Relevant Studies}

Research in the field of new institutional theory covers studies related to certain strategic responses of organizations to new structures that emerge in certain organizational fields at certain times, institutional elements that underlie the adaptation of organizations to rapidly diffusing new structures, and what kind of isomorphism the diffusion causes in the field. A study on the implementation of Total Quality Management (TQM) in 2700 hospitals focused on whether TQM was implemented in hospitals as an organizational activity or for the purpose of seeking legitimacy. It found that the first practitioners of TQM were not under the influence of institutional pressure and seeking effectiveness and efficiency, while subsequent practitioners implemented the program and adopted TQM mimetically due to the quest for legitimacy and normative institutional pressure, which caused an isomorphism in the field (Westphal et al., 1997). Özen's (2002) study on the diffusion of TQM in Turkey suggests that TQM has been adopted in Turkey mainly in a ceremonial way and with a concern for legitimacy, and thus fails to cause a radical change in organizations. Studies on commercial banks' responses to change and implementation in the institutional environment show the presence of legitimacy concerns 
and isomorphism in the organizational environment (Arslan, 2008; Deephouse, 1996). In another study, Sargut (2009) points out the fact that business management education in Turkey has mimicked the American model and that isomorphism has emerged in the institutional environment. The literature provides studies, carried out in various fields, related to the use of decoupling strategies by implementing certain structures solely on paper with concern for legitimacy. The organizations were claimed to have resorted to decoupling strategies in Lega et al. (2013) related to the diffusion of strategic management tools in public health organizations, in Tenhiala and Vuori (2012) with regard to the adaptation of compensation practices into human resources management in Finnish organizations, in Beverland and Luxton (2005) related to Integrated Marketing Communication (another management approach) and Powell and Bromley (2012) related to accountability. It is suggested that certain organizations adopt decoupling and symbolic compliance in Westphal and Zajac (2001), a study on the diffusion of Stock Repurchase Programs in the US in 1980 and 1990s, in Jamali (2010), a study related to the diffusion of International Accountability Standards, and in Fiss and Zajac (2006), a study on strategic responses of German organizations to change. There is a limited number of studies that refer to the new instituional theory for the evaluation of practices in the aviation sector. One of these studies was conducted by Sakyi and Azunu (2013) to investigate the operations of service providers at Ghana Airport through semi-structured interviews and focus groups with low, middle and high level managers selected through purposive sampling. The study suggests that decoupling was present due to internal causes conflicting with the air transportation industry. Farashahi (2003) evaluates, with respect to institutionalization processes, the functional operations of aviation organizations in a developing country. In the study, data was collected from managers and experts in the Iran air transport industry through interviews and questionnaires, and it was found that global regulations and norms had a large impact on organizational operations, and that national, regional and local pressure was less effective in the industry. Detra (2006) used qualitative methods to investigate the legitimacy of the Universal Safety Oversight Audit Programme and the regulatory power of the ICAO, as an international organization, in sovereign countries, and found that the program was legitimate and sustainable.

As a new system rapidly diffusing among aviation organizations, the SMS has drawn the interest of researchers and become the subject of academic studies from various perspectives. A model was developed in order to enhance the safety culture of employees and to raise awareness regarding organizational identity through data collected in the Taiwanese aviation industry, with a view to establishing an effective SMS for aviation organizations (Liou et al., 2008). In a study on possible challenges to the implementation of the SMS in aircraft maintenance organizations in Turkey, the data collected through open-ended questionnaires was analyzed by qualitative methods, and it was found that a strong positive safety culture played a role in the implementation of the SMS (Gerede, 2015a). Gerede (2015b) sought an answer to the same research question using the nominal group method, and found that a weak positive 'just culture' was possibly the most important challenge to the successful implementation of the SMS. The SMS has also been the subject of research related to safety perception, safety violations and the development of aviation safety (Gill, 2004), and related to safety management and culture (Gill \& Shergill, 2004). The SMS in the aviation industry has generally been dealt with in research related to abovementioned topics. There is a study focusing on the legitimacy of SMS practices 
in the maritime sector; a case study of eight ships and their crews (Vandeskog, 2015). However, with regard to the aviation industry, there are no studies that investigate the implementation of this new safety management practice from the perspective of the new institutional theory or any other institutional theory.

Undoubtedly, the SMS will serve its original purpose and contribute to the improvement of safety in aviation activities if it is adopted more consciously by organizations and if it goes beyond being merely a practice on paper and satisfies the requirements of a performance-based approach. A review of the literature does not provide any research, at the national or international level, on which changes this new approach caused in the institutional environment of aviation organizations, what responses the organizations gave to the adoption of the SMS, whether the approach was adopted rationally, whether the organizations had a dilemma between the technical environment and the institutional environment, and whether isomorphism emerged in the relevant organizational field. This study sets out to test the basic thesis of the new institutional theory in the aviation industry, to determine a connection between the theory and the SMS, and thus, to fill a gap in the literature.

\section{Methodology}

Qualitative research design is used in this study. The aim of qualitative research is not to reach generalizations, as it is the case in quantitative research, but to focus on meaning to obtain in-depth information related to a topic (Creswell 2008:204-205; 2012:16; Dey, 2005). Qualitative study relies on perceptions and comprehension of people (Stake, 2010:11). Perceptions and perspectives of actors and participants related to the field are important for the study, i.e. what they mean is important, and the researcher tries to understand their perceptions and perspectives by speaking to them (Creswell, 2013:186; Patton, 2002:4-5). For the present study, it was considered that data obtained from experts experienced in the launch and implementation of the SMS in aviation organizations and patterns obtained with the interpretation of the data were likely to provide answers to research questions. This is why qualitative research design that allows in-depth data collection was preferred.

In the study, primary data collecting methods, semi-structured interviews and notes taken in observations and secondary data collecting techniques, (i.e. examination of documents and research diary) were used.

Semi-structured interviews consist of open-ended questions and ensure flexibility. For example, they allow interviewers to add new questions during the course of the interview or ask questions in different ways (Hays \& Singh, 2012:239). The authors prefer this method because it enables them to obtain in-depth information related to the experience and perceptions of participants (Patton, 2002:17).

The interview questions were initially developed in view of a literature review and notes taken during field observations. The validity of the interview questions was ensured after they were evaluated by two academics specializing in the field and an academic who specializes, in the method, and tested in two subsequent pilot studies. A pilot study was carried out in this study, since it allows researchers to get an idea about a specific topic and to evaluate the research method, as well as interview and research questions (Glesne, 2013:74-75). Table 1 present detailed information related to the semi-structured interviews. 
Table 1: Semi-Structured Interview Data Collecting Table

\begin{tabular}{ccccl}
\hline $\begin{array}{c}\text { Code } \\
\text { Name }\end{array}$ & Date & Time & Duration & \multicolumn{1}{c}{ Data Collecting Mode } \\
\hline$P 1$ & 05.01 .2015 & 10.00 & $51 \mathrm{~min}$. & Interview and voice recording \\
\hline$P 2$ & 05.01 .2014 & 10.00 & $51 \mathrm{~min}$. & Interview and voice recording \\
\hline$P 3$ & 05.01 .2015 & 13.00 & $40 \mathrm{~min}$. & Interview and voice recording \\
\hline$P 4$ & 06.01 .2015 & 10.00 & $55 \mathrm{~min}$. & Interview and voice recording \\
\hline$P 5$ & 08.01 .2015 & 13.00 & $43 \mathrm{~min}$. & Interview and voice recording \\
\hline$P 6$ & 19.01 .2015 & 13.00 & $32 \mathrm{~min}$. & Interview and voice recording \\
\hline$P 7$ & 20.01 .2015 & 10.00 & $47 \mathrm{~min}$. & Interview and voice recording \\
\hline$P 8$ & 22.01 .2015 & 11.00 & $82 \mathrm{~min}$. & Interview and voice recording \\
\hline$P 9$ & 22.01 .2015 & 17.30 & $21 \mathrm{~min}$. & Interview and voice recording \\
\hline$P 10$ & 07.02 .2015 & 11.00 & $67 \mathrm{~min}$. & Interview and voice recording \\
\hline$P 11$ & 09.02 .2015 & 14.30 & $38 \mathrm{~min}$. & Interview and voice recording \\
\hline$P 12$ & 10.02 .2015 & 14.00 & $73 \mathrm{~min}$. & Interview and voice recording \\
\hline$P 13$ & 22.05 .2015 & 15.00 & $53 \mathrm{~min}$. & Interview and voice recording \\
\hline
\end{tabular}

Another data collection method used in the study was observation. Similar to interview, observation is a data collection method used in qualitative research (Merriam, 1998:94), which provides researchers with the advantages of recording any information when it is formed, having firsthand access to participants and observing extraordinary situations (Creswell, 2013:190-191; Merriam, 1998:96). This is why, in this study, where expert opinion is highly important, observations were made in meetings that brought together all stakeholders to discuss problems and opinions related to the SMS. In such environments, the participants are informed about the role of the researcher as an observer (Creswell, 2013:191; Merriam, 1998:101). The researcher participating in such an event is basically an observer, but also interacts with other participants (Glesne, 2013:87).

Three observations, as a participant, were made for the purpose of this study. Table 2 provides the details related to the date, place, duration, subject and mode of these observations.

The first observation presented in Table 2 was carried out in one of the organizations included in the scope of this study, i.e. an organization with the manager of which the researchers conducted a semi-structured interview. The organization had brought together, in its general directorate office, mid-level managers of its offices across the country to give them a one-week Safety Management System training, which is a legal requirement. The second observation 
presented in Table 2 was carried out in a two-day event focusing on State Safety Programmes and Safety Management Systems implemented by national authorities. The event was organized by the European Civil Aviation Conference (ECAC). Some aviation organizations that operate in Turkey participated in this event, where the Directorate General of Civil Aviation played the moderation role. The final observation shown in Table 2 was carried out in a workshop held under the auspices of the Directorate General of Civil Aviation. The participants of this workshop represented organizations that offer ground handling services, catering services, fuel services and terminal services, some of which took part in this study. This workshop provided a platform for sharing and discussing problems and issues related to the Safety Management System. Participation and observation in these events allowed interaction with international aviation authorities (ECAC members), the Turkish civil aviation authority (Directorate General of Civil Aviation) and aviation organizations that implement SMS based on these authorities' decisions. The researchers took field notes during observations to collect data. Field notes, generally based on dialogues (Glesne 2013:9), were used to develop interview questions and to support findings and interpretation of data collected in semi-structured interviews.

Table 2: Observations

\begin{tabular}{cccccc}
\hline No. & Date & Duration & Place & Subject & $\begin{array}{c}\text { Mode of } \\
\text { Observation }\end{array}$ \\
\hline 1 & $06-10.01 .2014$ & Five days & Istanbul & $\begin{array}{c}\text { Training on the Safety } \\
\text { Management System }\end{array}$ & $\begin{array}{c}\text { Observer as a } \\
\text { participant }\end{array}$ \\
\hline 2 & $19-20.02 .2014$ & $\begin{array}{c}\text { Two } \\
\text { days }\end{array}$ & Ankara & $\begin{array}{c}\text { State Safety Program } \\
\text { Practices (SSP) and } \\
\text { SMS Workshop }\end{array}$ & $\begin{array}{c}\text { Observer as a } \\
\text { participant }\end{array}$ \\
\hline 3 & 09.05 .2014 & One day & Ankara & $\begin{array}{c}\text { Workshop on the Safety } \\
\text { Management System }\end{array}$ & $\begin{array}{c}\text { Observer as a } \\
\text { participant }\end{array}$ \\
\hline
\end{tabular}

Another data collecting method in qualitative research is document examination, which provides a secondary source of data (Creswell, 2013:190). For the purpose of this study, the authors obtained and examined documents related to the SMS, including posters, booklets and handbooks. The authors did not carry out any content analysis on these documents, but used them for the purpose of reinforcing the trustworthiness of findings by comparing them with the results and interpretations of the qualitative interview data. The authors also kept a research diary throughout the research, which enabled them to note observations, ideas and personal notes and thus, to get an overview of the whole research process (Ünlüer, 2010:92). The field of research, where data was collected to answer research questions, comprises eleven organizations and the Turkish DGCA, which are assumed to play a direct role in the air transportation system. Detailed information about these organizations is presented in Table 3. 
Table 3: The Organizations Participating in the Research

\section{Organizations}

1 Directorate General of Civil Aviation

2 Sabiha Gökçen Airport Investment Development and Operation Inc.

3 TAV Istanbul Atatürk International Airport Terminal Operation Inc.

4 TAV Esenboğa Investment Development and Operation Inc.

5 Fraport IC İçtaş Antalya Airport Terminal Operation and Investment Inc.

6 Mondial Milas Bodrum Airport International Terminal Operation and Investment Inc.

7 Turkish Airlines DO-CO Catering Services Inc.

8 Sancak Inflight Services Inc.

9 LSG Sky Chefs Aviation Services Inc.

10 Turkish Ground Services TGS Inc.

11 Havaş Airport Ground Services Inc.

12 Çelebi Airport Services Inc.

The interviews in these organizations were performed with participants selected on the basis of purposive sampling. In purposive sampling, the researcher selects experts who are knowledgeable, experienced and in a position to represent the scope of the study in the best way (Berg, 2001:32; Ary et al., 2010:156). The participants in this study are SMS managers primarily charged with the launch and management of the SMS. For the purpose of this study, twelve SMS managers representing eleven aviation organizations were interviewed. Furthermore, a technical auditor representing the civil aviation authority, experienced in monitoring the SMS practices of organizations and performing audits in organizations, was interviewed following selection based on purposive sampling.

In this study, inductive and deductive methods were used together for qualitative data analyses. For the analyses, the steps suggested by Creswell were followed, i.e. data preparation and arrangement, reading all data, coding data and obtaining categories and themes (2008:185). The authors transcribed about eleven hours of voice recording obtained in semi-structured interviews and gathered 200 pages of interview transcriptions. Coding was performed individually by each author, and codes, categories and themes were ascertained in subsequent evaluation meetings. Because of the difference in nature between qualitative and quantitative research, validity and reliability are highly disputable concepts, and mainly correspond to trustworthiness in qualitative research (Glesne, 2013:65; Miles et al., 2014:311; Patton, 2002:541-547). There are various strategies in qualitative research used to ensure validity and reliability; in other words, to ensure the trustworthiness of findings (Creswell, 2008:219-223; Glesne, 2013:66; Miles et al., 2014:293-310). In this study, the measures taken to increase trustworthiness were the ensuring of the diversity of the data, describing the scope and time of the research, getting the consent of the participants, voice recording interviews and asking method and field experts to confirm the consistency of the methods. All data collected has been stored. 
It is plausible that a number of limitations might have influenced the results obtained. First, the scope of the study is delimited to Group A organizations offering ground handling, ground catering and terminal services in Turkey and the Directorate General of Civil Aviation, which is the national aviation authority. Another possible limitation is related to the use of semi-structured interviews. The number of participants interviewed was limited since the participatory organizations had only one manager responsible for the SMS, and that the number of people specialized in aviation safety is quite low. A voice recorder was used in semistructured interviews in order not to lose any data. The researchers were aware that the use of a voice recorder might prevent interviewees from expressing their views freely. Furthermore, the replies to interview questions were delimited to the participants' experience and perceptions. In the research, observations, i.e. the primary data collecting method, were restricted to field notes. Document analyses, i.e. the secondary data collection, were restricted to documents obtained from organizations including SMS leaflet, poster, manual, questionnaire and software as well as the diary kept by one of the researchers during the research.

To overcome abovementioned limitations, the researchers told the interviewees during semi-structured interviews that they were free to leave the session whenever they wished, voice recording could be interrupted whenever they wished, and voice recorder could not be used when they did not feel comfortable. Probes were used to avoid any misunderstanding of questions in interviews. Different types of data-collecting methods were combined, and data collected through different methods were compared to diversify the data, to rule out limitations specific to each method and to ensure that limitations do not hinder access to correct data.

\section{Findings and Interpretation}

\subsection{The Factors Governing the Diffusion of SMS}

The first research question of this study looks for factors that govern the diffusion of the SMS. As a result of inductive analysis of the data, 30 codes, 7 categories and 4 themes were obtained. The categories and themes are shown in Figure 1.

\section{Figure 1. The Factors Governing the Diffusion of SMS}

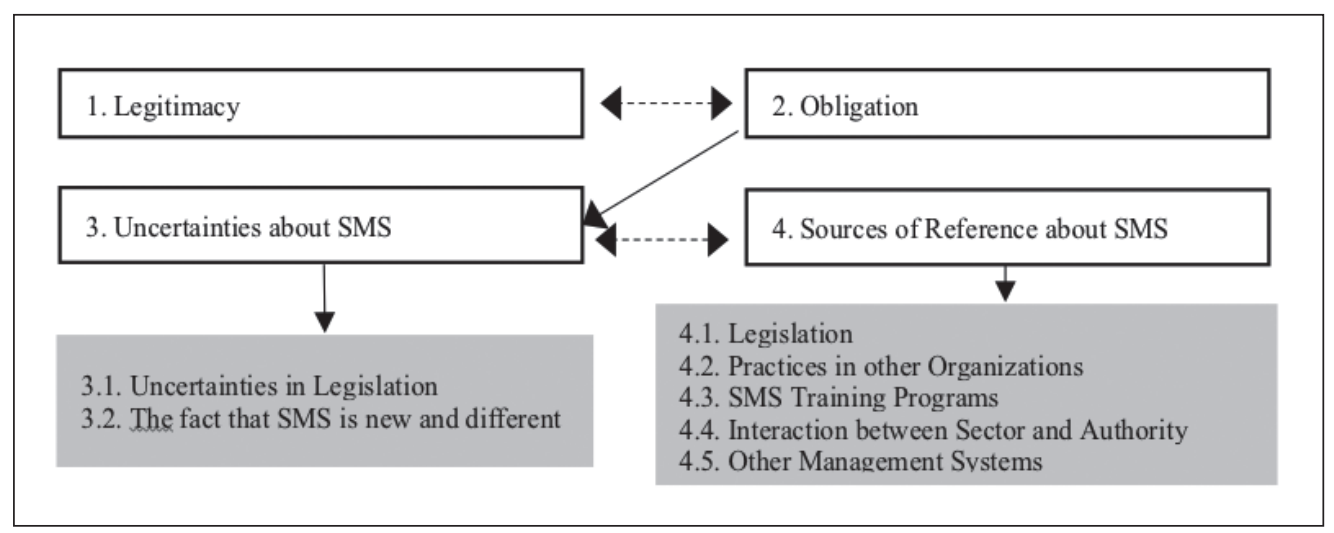


The first theme, legitimacy, indicates that the organizations view the adoption of the SMS as a means for gaining legitimacy. Participant 8 defines this as follows:

"The Civil Aviation Authority has first issued a regulation, and then a directive about this... We are an organization that complies with all regulation introduced by the public authority or previously introduced programs in a very short time. For, there is such a statement in our institutional structure: 'compliance management'... My goal is to ensure 'hundred percent compliance management'... We've already expressed in our company vision that we are an institutional organization; in such an organization, all requirements of the regulations are fulfilled one hundred percent."

The second theme, obligation, refers to the obligation to comply with the regulation of the ICAO and DGCA. The organizations see compliance with the regulation as a source of legitimacy on the one hand, and as an obligation on the other hand. The obligation is a fundamental factor that mobilizes organizations and underlies the diffusion of the SMS. Out of eleven organizations included in this study, ten organizations associated the factors that motivated them to implement the SMS with the legislation, while one organization referred to the obligation arising from the legislation and customers' demands. This is supported by P10 and P11, who commented that, "we started implementing the SMS when it became obligatory due to the regulation issued by the Directorate General of Civil Aviation", and P3, who said that, "what mobilized us was the obligation imposed by the DGCA. They motivated the company... If it hadn't been obligatory, we might not have implemented it." Adopting a system upon the demand of an actor on which the organization relies, although it would not be implemented under normal conditions, indicates the presence of coercive isomorphism (Özen, 2013:128; Dimaggio \& Powel, 1983:150).

All organizations that participated in this study began implementing the SMS in 2012 when the related regulation was issued by the DGCA. They had uncertainties related to the steps taken to implement this new management tool. This constitutes the third theme identified in the study. The following statement of P6 supports this finding: "We had many uncertainties. We really didn't know what to do, we still don't know indeed."

It was found that the organizations took as a model some reference guides in order to deal with the uncertainties deriving from the regulation and novelty of the practice, which is the fourth theme of this study. This resulted in the establishment of a connection between uncertainties and sources of reference. The fact that all organizations had recourse to the same sources in case of uncertainty, and that the main sources taken as a model were the regulation of authority, provide signals of coercive isomorphism (DiMaggio \& Powel, 1983:150). The diffusion of SMS is shown in Figure 2 from the perspective of new institutional theory.

In Figure 2, the field marked 1 shows the dependence of organizations on the DGCA and the reliance of the DGCA on the ICAO. The field marked 2 shows the sanction power of the ICAO over the DGCA and of the DGCA over organizations, as well as the direction of the relationship. In this respect, it may be concluded that the expedience of the authorities' sanctions constitute the basis of compliance SMS. The field marked 3 refers to the diffusion of rules issued by authorities into organizations' institutional environments through laws 
and regulations and the implementation of these rules, because of the dependence between authorities and organizations. The field marked 4 indicates that this situation causes a coercive isomorphism in the institutional field. Thus, it is possible to claim that the main factor underlying the diffusion of the SMS is the regulative pillar of institutions (Scott, 1995: 35).

These findings tend to support the basic thesis of the theory that organizations' structure and processes are shaped by their conformance to the institutional environment. The study provides findings similar to those in the literature with regard to the coercive effect of legislative tools on organizations, the importance of gaining legitimacy in the eyes of the authority and the emergence of isomorphism in the organizational field for all these reasons (Sargut, 2009; Arslan, 2008; Deephouse, 1996; DiMaggio \& Powell, 1983; 1991). With regard to this research question, this study provides results parallel to the ideas that constitute the basis of Meyer and

Figure 2. The Institutional Pressure Elements Underlying the Diffusion of SMS and Their Diffusion in the Field

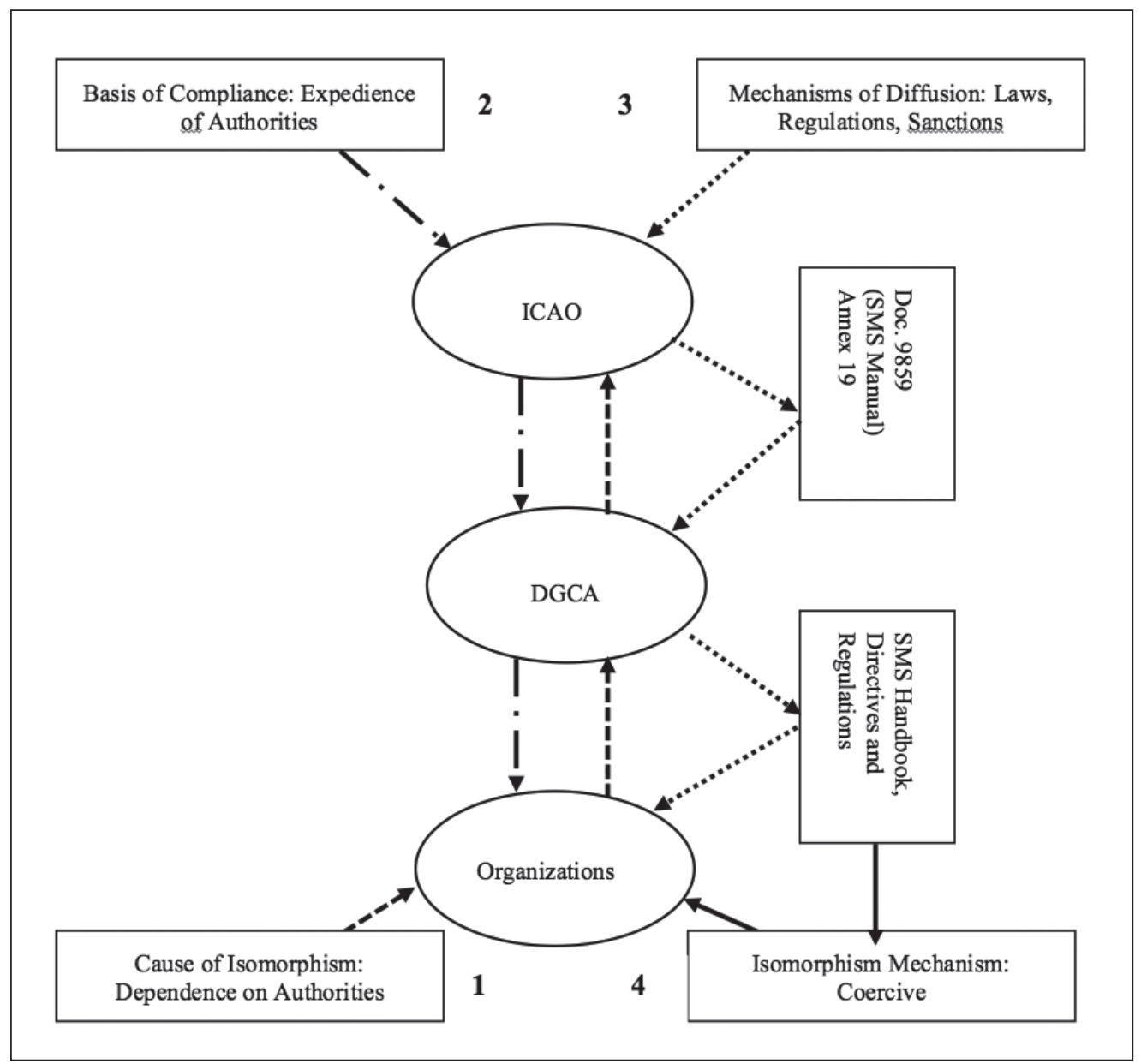


Rowan's (1977) theory, i.e. the fact that organizations strive to gain legitimacy and survive by adopting the practices in their institutional environment, and that this causes isomorphism in the organizational field.

\subsection{The Strategic Responses to Institutional Pressure Related to SMS}

Another research question of this study seeks to find which strategies defined by Oliver (1991), i.e. acquiesce, compromise, avoidance, defiance and manipulation, are more dominant with regard to the implementation of the SMS. The inductive analysis of qualitative data provided 65 codes, 7 subcategories, 6 categories and 4 main themes. The subcategories, categories and themes are presented in Figure 3.

Figure 3 shows that the concept of legitimacy, which is highly emphasized in the theory, is the first theme related to this research question. The new institutional theory suggests that organizations look for legitimacy when they conform to beliefs and values in the institutional environment, and that by doing so, they gain access to resources and survive (Pfeffer \& Salancik, 1978; DiMaggio \& Powell, 1983; Suchman, 1995). This is why legitimacy is an indispensable element for the survival of organizations (Meyer \& Scott, 1983; Meyer \& Rowan, 1991). It is found in this study that the organizations that participated in the study also give importance to legitimacy and see the implementation of the SMS as a requirement for gaining legitimacy in the institutional environment. The legitimacy mentioned here is a pragmatic legitimacy based on rational interest and compliance with regulations (Suchman, 1995: 578). The diffusion of the SMS by the state, i.e. the dominant actor in the institutional environment, entails organizations

Figure 3. The Relationship of Strategic Responses to Institutional Pressure

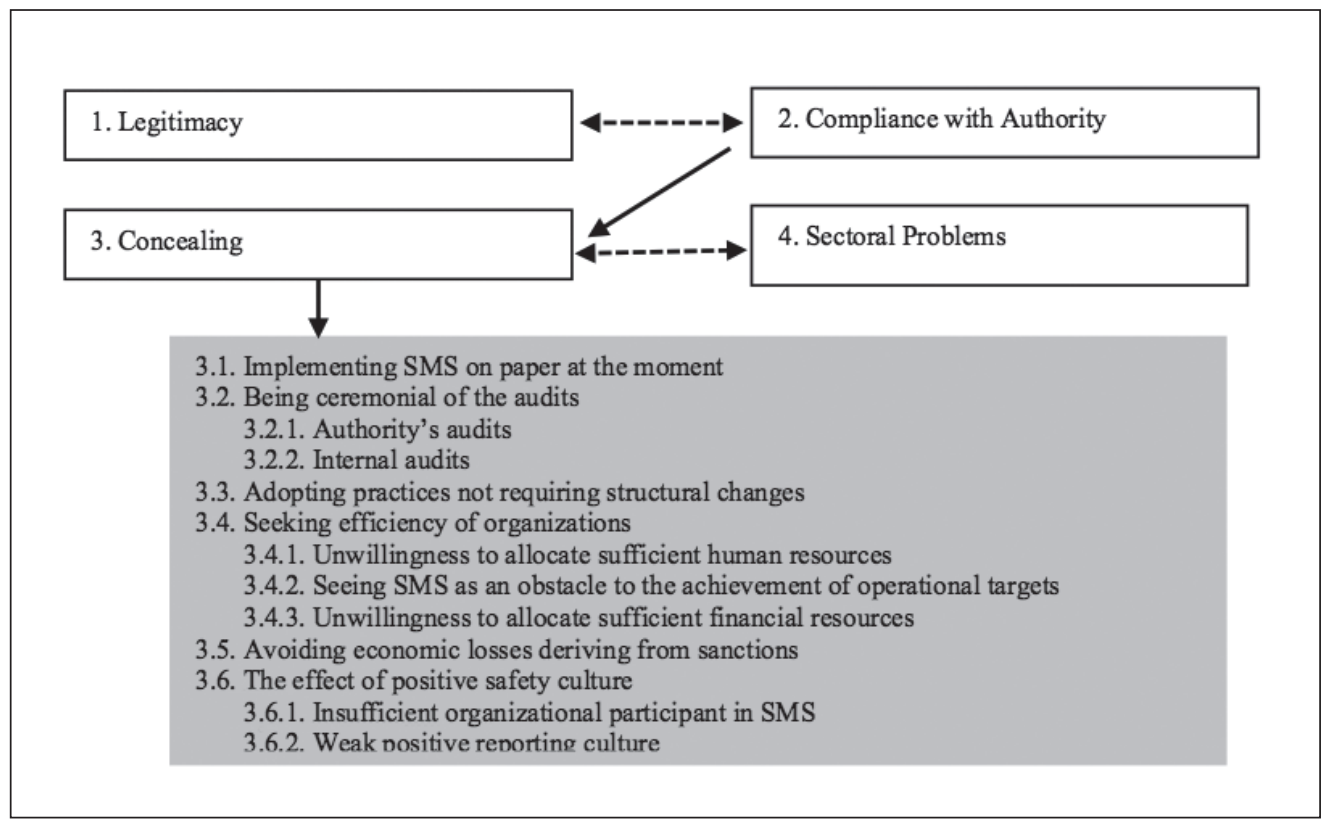


to comply with the authority. "Since implementation was obligatory after that time, it has inevitably become a part of our life," said P1, and, "Action was taken... We immediately developed a four-stage implementation plan... It was already an obligation," said P10 to define this obligation. P3 asked, "How possible? How possible could it be?" and P9 said, "It was impossible" not to implement the SMS. The organizations see it as obligatory to comply with regulations imposed by the state on which they are strongly dependent. Compliance and legitimacy support each other because compliance makes organizations earn legitimacy in the eyes of the state. At this point, compliance with the ICAO and DGCA regulations appears to be the second theme.

Another theme in this context is concealing. While organizations ostensibly give acquiescence and compliance responses to institutional pressure by the state, which is a powerful actor in their institutional environment, an in-depth examination of steps taken or not taken indicates that eight out of eleven organizations adopt concealing, which is one of the strategic responses suggested by Oliver (1991:151). This inference is based on the emphasis that the SMS has been launched in procedural terms on paper, but expectations from a performancebased approach and proactivity requirements have not yet been fulfilled. The relevant findings may be summarized as follows: the participants believe that audits are of only ceremonial in nature because so far no sanctions have been implemented and audits are for now only capable of measuring practices on paper; the organizations preferred practices that do not require radical changes and tended to conform to the standard model, rather than adapt the process into organizational structure; there is no distinction between human and financial resources unless necessary, because of the demand for efficiency; the SMS is seen as an obstacle to operational targets; and organizational participation in practice is low.

The last theme in this structure is sectoral problems. Significant problems arising from the specific nature of the sector, i.e. infrastructural deficiencies, common field of working, bureaucratic barriers, attitude of an airport authority, lack of co-ordination between the DGCA and the airport authority, time pressure and heavy air traffic constitute obstacles to the successful implementation of the SMS. In a similar vein, as the SMS cannot be put into practice in the expected way because of a concealing strategy, the SMS culture fails to develop and responsibilities are not shared, there is no collective consciousness between organizations working together, the operation is of primary importance because of the quest for efficiency and such behavior is likely to aggravate sectoral problems.

In summary, eleven organizations began implementing the SMS with the regulation adopted in 2012; however, it was found out that all these organizations have since displayed ostensible acquiescence (compliance) behavior. Concealing, a theme that emerges as a result of an in-depth examination of SMS practice, is one of the subcategories of Oliver's (1991) avoidance strategy and is seen in eight of the eleven organizations in this study.

It can be seen that the organizations that participated in this study have oscillated between earning legitimacy through compliance with the SMS, which has spread rapidly in the institutional environment with the coercive mechanisms of the authority on the one hand, and maintaining technical efficiency on the other hand. Because the state is the source of institutional pressure, the organizations that are highly dependent on the authority have not adopted active 
strategies such as defiance and manipulation, and preferred ostensible compliance with the regulation. On the other hand, the organizations that do not desire to compromise their technical efficiency have ensured procedural compliance with the SMS regulation, but this compliance has been restricted to on-paper procedures in most of these organizations. This result, obtained from the categories of concealing strategy, demonstrates that eight organizations implement the SMS in a procedural way and continue with their old practices, but keep their legitimacy in the eyes of the authority on the one hand, and maintain their efficiency and effectiveness in their own way on the other hand. By doing so, they decouple the SMS from organizational processes.

In three organizations, the SMS was launched because it was an obligation. However, over time, these organizations found the SMS useful and integrated it into organizational practices and internalized it. It was seen that these organizations allocated more funding for the SMS and displayed certain original behavior. Thus, eight organizations in this study adopted the avoidance strategy and concealed SMS practices, while three organizations adopted the acquiesce strategy and conformed to rules and norms. The results of this study support the findings in the literature, which indicate that, under institutional pressure, organizations comply with the practice for which the pressure is applied to earn legitimacy in the institutional environment, but on the other hand develop decoupling strategies to maintain their technical efficiency (Özen, 2002; Beverland \& Luxton, 2005; Jamali, 2010; Powell \& Bromley, 2012; Westphal \& Zajac, 2001; Taylor \& Oylan, 2008; Fiss \& Zajac, 2006).

\subsection{The Manner of Adopting the SMS}

The third research question seeks to discover whether the SMS is adopted in a ceremonial or in a rational way. Actors assume a significant role in the development, diffusion and survival of new practices in the institutional field (Scott et al., 2000). It is known that the state is a powerful actor that has authority over organizations in the institutional field (DiMaggio \& Powell, 1991:67). The state, defining the legal boundaries of the institutional field, demands compliance with laws and regulations. Such compliance is the source of legitimacy for organizations (Deephouse \& Suchman, 2008:56), which increases their survival chance (Meyer \& Rowan, 1977:353). This why legitimacy is closely related to the diffusion of new practices and institutionalization (Deephouse \& Suchman, 2008:58). Organizations aspiring to gain legitimacy in the face of an actor on whom they are dependent in terms of resources and survival tend to conform to regulations introduced by the actor in the institutional field (Boxenbaum \& Jonsson, 2008:87; Oliver, 1991). The pressure caused by the state, owing to its power of sanction, is mostly accepted, yet change is not always easily adopted in the institutional field (Vermeulen et al., 2007:532). Pressure may lead organizations to display concealing behavior (Seidman, 1983), and thus, to adopt the system in a ceremonial way.

The second research question shows that most of the organizations take up the concealing strategy and prefer symbolic compliance, which indicates that ceremonial adoption is more common. The method of decision making is also important, as it is an indicator of how a system is adopted (Özen, 2002:75). The present study shows that none of the eleven organizations adopted the SMS after making a cost-benefit analysis, and by regarding it as a useful practice. The participants exhibited signals of having implemented the SMS blindly. A number of 
statements from the participants support this finding: "To tell the truth, we established SMS not because we see it useful, but because we had to. If it hadn't been obligatory, no one would have been willing to implement the SMS. This is the reality. No one would...," said P6, one of the interviewees. "No, we didn't. You know many organizations are unlikely to adopt it if it wasn't obligatory. In other words, no employers would adopt it. In no field, not only in aviation... Thus, we adopted the SMS because it was obligatory," said P9. "No, we started rashly. The authority issued a regulation and forced us to implement it within a certain period. So, we didn't have much chance," stated P11.

The participants were asked about the contributions of the SMS, implemented ostensibly since 2012, to the organization. Most of the participants stated that the SMS was, for now, at the procedural level and that the requirements of a performance-based approach had not yet been fulfilled in practice. These statements support the findings of this study.

In order to support the findings and reinforce the trustworthiness of this study, we asked the participants their opinions on whether the SMS was being put into practice by organizations in the sector, considering that they were all under the influence of the same institutional pressure. The majority of participants argued that the SMS had not yet been put into practice completely and had not been adopted in a rational way. This also seems to support the findings.

In summary, it is concluded that this new system has been adopted in a ceremonial way, considering together the results related to when the organizations adopted the SMS, their manner of decision-making and the participants' opinions on the benefits of the SMS and whether or not it was put into practice in the sector. This result supports studies concluding that new practices or management systems mentioned in the literature are adopted by organizations, not for profit in the technical and economic environment, but because of pressure from the institutional environment, and that the implementation of new systems because of a concern for legitimacy has a ceremonial nature (Özen, 2002; Westphal, 1997; Meyer \& Rowan, 1977).

\subsection{Examination of Documents}

During the semi-structured interviews, four of the eleven organizations provided SMS-related bulletins, manuals, posters, questionnaires and a copy of software developed for the SMS. In the previous section, it was found that out of the eleven organizations, eight adopted concealing and three adopted compliance strategies. Two of the organizations that provided documents for this study were from amongst the eight organizations that had adopted concealing strategies, and two were from amongst the three organizations that had adopted compliance strategy. This result was compared with the content of documents obtained from the organizations. It was seen that the documents of organizations that were considered to have adopted concealing strategies had one-to-one compliance with the standard model, and that their safety bulletin and policies fully conformed to examples in the directive, and that these organizations did not attempt to make any original adaptation. On the other hand, two organizations that were considered to have adopted compliance strategies and that claimed to have displayed original behavior during interviews, reflected these behaviors on documents and exerted efforts to implement the SMS in their organizational context. In brief, comparing the documents provided by four organizations and the interview findings of these organizations, we see that these two sources of data completely support each other. 


\subsection{A General Overview of the Implementation of SMS}

The relationship between three research questions in this study and the general overview of the implementation of the SMS seen in this study are presented in Figure 4.

In Figure 4, the part marked 1 shows that the SMS was adopted because of pragmatic legitimacy and obligation in all the organizations that participated in this study, and the part marked 2 indicates that eight organizations, which complied ostensibly with the authority because of obligation, gave concealing responses to the system; one of the avoidance strategies suggested by Oliver (1991). The part marked 3 indicates that the SMS was adopted in a ceremonial way when the following components are considered together; concealing response, time of adopting SMS, way of deciding to implement the SMS and method of implementing the SMS. Finally, the part marked 4 shows that the ceremonial adoption of SMS resulted in isomorphism in the organizational field, and that isomorphism supports obligation and legitimacy with respect to the implementation of the system.

Figure 4. A General Overview of the Implementation of SMS

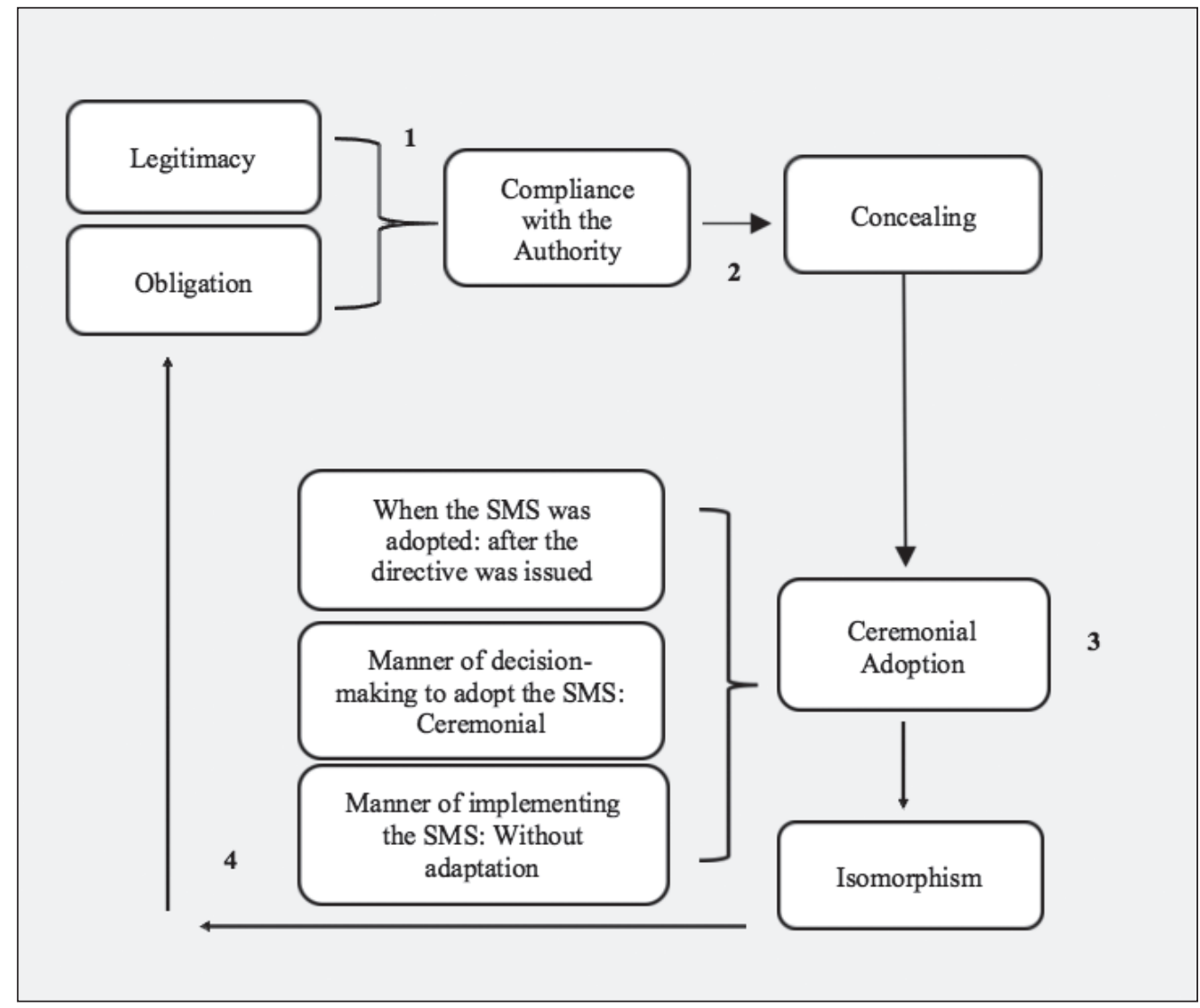




\section{Conclusion}

This study makes an evaluation of SMS practices rapidly diffusing in the field of aviation from the perspective of new institutionalism. The research covers eleven organizations and the DGCA. The data collected from primary and secondary sources was used to answer three research questions. This study tests the theses of new institutionalism that organizations' structures and processes are shaped as a result of their adaptation to the institutional environment. In addition, it tests that organizations are engaged in new practices not only to ensure technical efficiency but also to earn legitimacy in the institutional environment even at the cost of compromising technical efficiency, and that they become isomorphic by conforming to similar structures of the same institutional environment (Meyer \& Rowan, 1977; DiMaggio \& Powell, 1983; Deephouse, 1996; Özen, 2010).

In this study, it is found that the SMS was not implemented by any organization before legislation was issued by the DGCA, and that all organizations adopted it after the DGCA directive. This supports Tolbert and Zucker's (1983:28) finding that when it is the state that entails the implementation of any practice, its diffusion is faster. finding that when the state entails the implementation of any practice, its diffusion is faster. This study has shown that a concealing strategy was adopted by eight of the eleven organizations. This finding also supports previous results that organizations may oscillate between a concern for legitimacy in the institutional environment and a concern for continuing their effectiveness and efficiency, and that they prefer a decoupling strategy to balance between two concerns (Powell \& Bromley, 2012; Fiss \& Zajac, 2006; Westphal \& Zajac, 2001; Meyer \& Rowan, 1977). Another finding is that the organizations that participated in this study adopted SMS in a ceremonial way. This supports the results that, as suggested by the theory, the structures that emerge due to institutional pressure in the institutional environment are not always adopted in a rational way in quest for effectiveness and efficiency, rather they are adopted in a ceremonial way to avoid institutional pressure, which in turn causes organizations to make decisions blindly and to adopt and implement practices only on paper (Özen, 2002; Westphal, 1997; Meyer \& Rowan, 1977).

In general terms, this study provides results that reinforce the theses introduced by new institutionalism and overlap with findings already available in the literature. However, Oliver (1991:152) contends that, in the face of pressure in the organizational environment, organizations are likely to develop strategies based on the source of pressure, actors causing pressure, the way in which pressure is exerted, resource dependence of organizations on actors, and the legitimacy ensured by compliance. Oliver (1991:160) argues that as the level of coercion, legitimacy and gains decreases, resistance to the institution increases and organizations become engaged in active strategies. When the state on which organizations are dependent causes institutional pressure by laws, organizations follow a passive strategy, as the sanction of noncompliance with the authority is likely to be heavy, and consider that the level of legitimacy arising from compliance with pressure is likely to be high. The literature is abundant in studies that support Oliver (Abernethy \& Chua, 1996; Sotiriadou \& Wicker, 2013; Clemens \& Papadakis, 2008; Pedersen \& Gwozdz, 2014; Raaijmakers et al., 2015; Etherington \& Richardson, 1994; Ingram \& Simons, 1995; Goodstein, 1994; Fareed et al., 2015). In this respect, the present study suggests that the diffusion of the SMS depends on coercive tools, such as regulations and directives posed by the state, yet pragmatic legitimacy based on rational 
interests and compliance with rules (Suchman, 1995; Özen, 2013:126) is more important in the eyes of participants. It is a result that does not correspond with Oliver's argument that eight out of eleven organizations in this study adopted the concealing response, one of the avoidance strategies, while they were expected to acquiesce and comply with the authority with regard to the implementation of the SMS. This is a noteworthy result, and the reason why eight organizations displayed avoidance behavior while only three organizations tended to acquiesce coercive institutional pressure should be discussed. This may be explained by findings that present only the existence of a concern for pragmatic legitimacy in the field and lack of any SMS-related perception based on moral and cognitive legitimacy in the sector. The fact that the SMS is a new practice and differs from safety management approaches implemented so far (Gerede, 2015a; 2015b) is also likely to cause challenges in putting the SMS into practice and to force organizations to concealing. SMS is a new and rapidly diffusing management system, not only in Turkey, but also across the world. Studies carried out in various countries are likely to provide answers to SMS-related questions.

\section{References}

Abernethy, A., \& Chua, W. (1996). A field study of control system "Redesign": The impact of institutional processes on strategic choice. Contemvoran Accounting Research, 13(2), 569-606.

Armour, H. O., \& Teece, D. T. (1978). Organizational structure and economic performance: a test of the multidivisional hypothesis. The Bell Journal of Economics, 9(1), 106-122. Retrieved September 20, 2014, from http://www.jstor.org/stable/3003615

Arslan,R.(2008). Türk bankacılık sisteminde rekabet startejileri ve yayılım süreci. [Competition strategies in turkish banking system and diffusion process]. Uşak Üniversitesi Sosyal Bilimler Dergisi, 1(2), 125-141.

Ary, D., Jacobs, L. C., Sorensen, C., \& Razavieh, A., (2010). Introduction to research education. Eighth ed., USA: Wadsworth Cengage Learning.

Berg, B., (2001). Qualitative research methods for the social science fourth ed., USA: A Pearson Education Company.

Beverland, M., \& Luxton, S., (2005). Managing integrated marketing communication (IMC) through strategic decoupling. Journal of Advertising, 34(4), 103-116.

Boxenbaum, E., \& Jonsson, S., (2008). Isomorphism, diffusion and decoupling. In: Greenwood, R., Oliver, C., Suddaby, R., Sahlin K. (Eds), Organizational Institutionalism, 78-98.

Clemens, B. W., \& Dougles, T. J., (2005). Understanding strategic responses to institutional pressures. Journal of Business Research, 58, 1205-1213.

Clemens, B. W., \& Papadakis, M. (2008). Environmental management and strategy in the face of regulatory intensity: radioactive contamination in the us steel industry. Business Strategy and the Environment, 17, 480-492.

Creswell, J. W. (2008). Research design: Qualitative, quantitative and mixed methods approachs. Third ed., Sage Publication. 
Creswell, J. W. (2012). Educational research: Planning, conducting and evaluating quantitative and qualitative research. Fourth ed., Boston: Pearson.

Creswell, J. W. (2013). Araştırma deseni: Nitel, nicel ve karma yöntem yaklaşımları., (Research design: Qualitative, quantitative and mixed methods approaches). Demir, S. B. (Ed.) Ankara: Eğiten Kitap.

Deephouse, D. (1996). Does isomorphism legitimate? The Academy of Management Journal, 39(4), 1024-1039.

Deephouse, D.L., \& Suchman, M. (2008). Legitimacy in ogranizational institutonalism. In Greenwood, R., Oliver, C., Sahlin, K., \& Suddaby, R. (Eds.), The Sage Handbook of Organizational Institutionalism (pp. 49-77). Thousand Oaks, CA: Sage.

Detra, Z. D. (2006). The legitimacy of the International Civil Aviaiton Organziation's universal safety oversgiht audit programme. Montreal: Institute of Air and Space Law Faculty of Law McGill University.

Dey, I. (2005). Qualitative data analysis: A user-friendly guide for social scientist. Taylor and Francis e-Library.

Dimaggio, P. J., \& Powell, W. W. (1983). The iron cage revisited: institutional isomoprhism and collective rationality in organizational fields. American Sociological Review, 48(2), 147-160.

Dimaggio, P., \& Powell, W. (1991). The iron cage revisited: Instutional isomorphism and collective rationality in organization fields. The new institutionalism in organizational analysis, 63-82. The University of Chicago.

Directorate General of Civil Aviation. (2011). Safety management manuel.

Directorate General of Civil Aviation. (2012a). Basis of safety management system.

Directorate General of Civil Aviation. (2012b). Havaalanlarında Emniyet Yönetim Sistemi'nin uygulanmasina ilişkin talimat. (The instructions regarding the implementation of the Safety Management System in Airports).

Directorate General of Civil Aviation. (2012c). Havacılıkta Emniyet Yönetim Sistemi Yönetmeliği (Regulations of Safety Management System in aviation). Turkish official gazette no. 28172. 13 January 2012.

Erel, D. (2002). Yeni kurumsalcı yaklaşım örgütlerin analizinde bir paradigma değişimine işaret ediyor mu? (Does the new institutional teheory mark a paradigm shift in the analysis of organizaitons?) Abant İzzet Baysal Üniversitesi Sosyal Bilimler Enstitüsü Dergisi, 2, 88-107.

Etherington, L. D., \& Richardson, A. J. (1994). Institutional pressures on university accounting in Canada. Contemporary accounting research, 10, 141-162. DOI: 10.1111/j.19113846.1994.tb00426.x

Farashahi, M.(2003). Institutionalization process within organizations: A multilevel analysis of two functional activities of airlines in a developing country. Montreal, Quebec, Canada: The Department of Management of the John Molson School of Business.

Fareed, N., Bazzoli, G. J., Mick, S., \& Harles, D. W. (2015). The influence of institutional pressures on hospital electronic health record presence. Social Science and Medicine, $133,28-35$. 
Federal Aviation Administration. (2004). Safety management system manual.

Federal Aviation Administration. (2014). Safety management system manuel. FAA Air Traffic Organization.

Fiss, C. D., \& Zajac, E. (2006). The symbolic management of strategic change: sensegiving via framing and decoupling. Academy of Management Journal, 49(6), 1173-1193.

Gerede, E. (2015a). A qualitative study on the exploration of challenges to the implementation of the Safety Management System in aircraft maintenance organizations in Turkey. Journal of Air Transport Management, 47, 230-240.

Gerede, E. (2015b). A study of challenges to the success of the safety management system in aircraft maintenance organizations in Turkey. Safety Science, 73, 106-116.

Gill, G. K. (2004). Perception of safety, safety violation and improvement of safety in aviation: Findings of a pilot study. Journal of Air Transportation, 9(3), 43.

Gill, K. G., \& Shergill, G. (2004). Perceptions of safety management and safety culture in the aviaiton industry in New Zealand. Journal of Air Transport Management, 10, 233-239.

Glesne, C. (2013). Nitel araştırmaya giriş. In A. Ersoy, P. Yalçınoğlu (Eds), Introduction to Qualitative Research (3rd ed.). Ankara: Anı Yayıncılık.

Goodstein, J. D. (1994). Intitutional pressures and strategic responsiveness: Employer involvement in work-family issues. Academy of Management Journal, 37(2), 350-382.

Greenwood, R., \& Hinings, C. R. (1996). Understanding radical organizational change: Bringing together the old and new institutionalism. Academy of Management Review, 21(4), 1022-1054.

Greenwood, R., Suddaby, R., \& Hinings C.R. (2002). Theorizing change: The role of professional associations in the transformation of institutionalized fields. Academy of Management Journal, 45, 58-80.

Gürol, Y. (2005). Örgüt teorisi olarak kurumsalaşma, (Institutinalization as an organization theory) First ed., İstanbul: Beta.

Hays, D., \& Singh, A. (2012). Qualitative inquiry in clinical and educational settings. New York: The Guilford Press.

International Civil Aviation Organziation. (2006). Safety management manuel. 1 st ed.

International Civil Aviation Organization. (2009). Safety management manuel (SMM) Doc 9859 AN/474, $2^{\text {nd }} \mathrm{Ed}$.

International Civil Aviation Organization. (2013a). Safety management manuel. Doc 9859 AN/474, Montreal.

International Civil Aviation Organization. (2013b). Annex 19. safety management. Retrieved February 02, 2014, from http:/www.icao.int/safety/SafetyManagement/Documents/ Doc.9859.3rd\%20Edition.alltext.en.pdf

International Civil Aviation Organization. (2014). Safety report. Montreal, Canada. Retrieved February 02, 2014, from http://www.icao.int/safety/Documents/ICAO_2014\%20 Safety\%20Report_final_02042014_web.pdf (Feb, 02, 2014)

Ingram, P., \& Simons, T. (1995). Instutional and reseource dependence determiantions of responsiveness to work-family issues. Academy of Manadement Journal, 38, 1466-1482. 
Jamali, D. (2010). MNCs and international accountability standars through an institutional lens: Evidence of symbolic conformity or decoupling. Journal of Business Ethics, 95 , 617-640.http://www.jstor.org/stable/40836203?seq=1\#page_scan_tab_contents

Kırkbeşoğlu,E. (2011). Strategic reactions of organizations to legal environment: A typology for industries in the process of institutionalization. Procedia Social and Behavioral Sciences, 1322-1328. http://www.sciencedirect.com/science/article/pii/S1877042811015552

Lega, F., Longo, F., \& Rotolo, A. (2013). Decoupling the use meaning of strategic plans in public healthcare. BMC Health Services Research, 13(5), 1.

Liou, J. H., Yen, L., \& Tzeng, G. (2008). Building an effective safety management system for airlines. Journal of Air Transport Management, 20-26.

Maher, S. T., Long, C., R.S., C., Sutton, L., \& Steinhilber, M. (2013). Paradigm shift in the regulatory application of safety management systems to offshore facilities. Process safety progress, http://onlinelibrary.wiley.com/doi/10.1002/prs.11558/abstract

Merriam, S. (1998). Qualitative research and case study applications in education: revised and expanded from case study research in education. San Franciso: Jossey Bass.

Meyer, J. W., \& Rowan, B. (1977). Institutionalized organizations: Formal structure as myth and ceremony. American Journal of Sociology, 83, 340-363.

Meyer, J. W., \& Scott, W. R. (1983). Centralization and the legitimacy problems of local government. Newbury Park: Sage.

Meyer, J., \& Rowan, B. (1991). Institutionalized organizations: Formal. In: Powel, W., Dimaggio, P. The new intitutionalism in organizational analysis (pp. 41-62). Chicago: University of Chicago Press.

Miles, M. B., \& Huberman, A. M. (1994). Qualitative data analysis: An expanded sourcebook. 2nd Ed., Thousand Oaks, CA: Sage.

Miles, M., Huberman, A., \& Saldana, J. (2014). Qualitative data analysis. 3rd Ed., USA: Sage.

Morrill, C., \& Mckee, C. (1993). Institutional isomorphism and informal social control: Evidence from a community mediation center. Social Problems, 40(4), 445-463. Retrieved March 15, 2014, from http://scholarship.law.berkeley.edu/cgi/viewcontent. cgi? article $=1956 \&$ context $=$ facpubs

Oliver, C. (1991). Strategic respons to institutional processes. The Academy of Management Review, 16(1), 145-179.

Özen, Ş. (2002). Bağlam, aktör, söylem ve kurumsal değişim: Türkiye'de toplam kalite yönetimin yayılım süreci. (Context, actors, discourse and intitutional change: Diffusion process of total quality management in Turkey), Yönetim Araştırmaları Dergisi, 1(2), 47-90.

Özen, Ş. (2010). Yeni kurumsal kuram: Örgütleri çözümlemede yeni ufuklar ve yeni sorunlar. [New institutional theory: New horizons and problems in organizational analysis]. In Sargut, A. S., Özen, Ş., (Eds.), Örgüt Kuramları [Organization Theories], (pp. 237330). Ankara: İmge Kitabevi.

Özen, Ş. (2013). Yeni kurumsal kuram. [New institutional theory], In: Taşc1, D., Erdemir, E., (Eds.) Örgüt Kuramı [Organization Theory], (pp. 120-138). Eskişehir: Anadolu Üniversitesi Açıköğretim Fakültesi Yayınları. 
Parsons, T. (1956). Suggestions for a sociological approach to the theory of organizations II. Administrative Science Quarterly, 1(2), 225-239.

Parsons, T. (1960). Structure and process in modern societies. Glencoe, IL: Free Press.

Patton, M. (2002). Qualitative research and evaluation methods. California: Sage.

Pedersen, E. R., \& Gwozdz, W., 2014. From resistance to opportunity-seeking: Strategic responses to institutional pressures for corporate social responsibility in the Nordic fashion industry. J Bus Ethics, 119, 245-264.

Perrow, C. (1984). Normal accidents; living with high risk technologies. USA: Basic Books.

Pfeffer, J., \& Salancik, G. R. (1978). The extenal control of organizations: A resource dependence perspective. New York: Harper and Row: Stanford University, 2003.

Powell, W., \& Bromley, P. (2012). From smoke and mirrors to walking the talk: Decoupling contemporary world. The Academy of Management, 1, 1-48. http://www.tandfonline. com/doi/abs/10.1080/19416520.2012.684462

Raaijmakers, A. G., Vermeulen, P. A., Meeus, M. T., \& Zietsma, C. (2015). I need time! Exploring pathways to compliance under institutional complexity. Academy of Management Journal, 58(1), 85-110.

Sakyi, E., \& Azunu, R. (2013). Ghana Airport Company Limited's decoupling experience: Achievements, challenges and policy lessons. Global Journal of Management and Business Research, 13(8).

Sargut, A. (2009). Türkiye'de işletme yönetimi eğitiminin kurumsal çevresi: Çeşitlilikten eşbiçimliliğe. (Institutional field of management training in Turkey: From diversity to isomorphism). Eskişehir Osmangazi Üniversitesi İ̈BF Dergisi, 4(1), 51-63.

Scott, W. R., Mendel, P. J., \& Caronna, C. A. (2000). Institutional change and healthcare organizations: From professional dominance to managed care. Chicago: University of Chicago Press.

Seidman, W. (1983). Goal ambiguity and organizational decoupling: the failure of "rational systems" program implementation. Educational Evaluation and Policy Analysis, 5(4), 399-413.

Selznick, P. (1949). TVA and the grassroots: A study in the sociology of formal organziations. New York: Harper Torchbooks.

Selznick, P. (1957). Leadership in admiistration: A sociological interpretation. Berkeley: Univeristy of California.

Selznick, P. (1996). Institutionalism "Old" and "New". Administrative Science Quarterly, 41(2), 270-277.

Sotiriadou, P., \& Wicker, P. (2013). Community sports clubs' responses to institutional and resource dependence pressures for government grants. Annals of Leisure Research, 16(4), 297-314.

Stake, R. (2010). Qualitative research: Studiyng how things work. New York: The Guilford Press.

Suchman, M. C., (1995). Managing legitimacy: Strategic and institutional approaches. Academy of Management Review, 20(3), 571-610. 
Taylor, D., \& Oylan, L. (2008). Environmental reporting by city goverments in Australia: Influences of isomorphism, decopuling and management dominant logic. Muhasebe Bilim Dünaysı Dergisi, The World of Accounting Science (3), s. 7-23.

Tayşir, E. A., \& Anıl. İ. (2011). Kurumsal baskılara verilen örgütsel yanıtlarda kritik karar alıcıların tehdit fırsat algısının rolü: İMKB' de işlem gören bankaların kurumsal yönetim ilkeleri karşısındaki davranışları üzerinden bir değerlendirme. (The role of the key decision makers' threat-opportunity perception on organizational responses to institutional pressures: An evaluation through the corporate governance behaviors of publicly owned turkish banks). Yönetim Arasstırmaları Dergisi, 11(1-2), 79-110.

Tenhiala, A., \& Vuori, T. (2012). Decoupling compensation practices from human resource management. International Studies of Management and Organization, 42(1), 7-23.

Tolbert, P. S., \& Zucker, L. G. (1983). Institutional sources of change in the formal structure of organizations: The diffisuon of civil reform 1880-1935. Administrative Science Quarterly, 28, 22-39.

Transportation Research Board, (2009). ACRP report 1: Safety management system for airports. 2. Washington, D. C.

Ünlüer, S. (2010). Engelliler Entegre Yüksekokulu'ndaki bilgi ve iletişim teknolojileri entegrasyonu sürecinin incelenmesi (Examining the process of information and communication technologies integration at the school for the handicapped). Doctoral dissertation thesis, Anadolu University Graduate School of Educational Sciences, Eskişehir, Turkey.

Vandeskog, B. (2015). The legitimacy of safety management systems in the minds of Norwegian seafarers. The International Journal on Marine Navigaiton and Safety of Sea Transportation, 9(1), 101-106.

Vermeulen, P., Buch, R., \& Greenwood, R. (2007). The impact of governmental policies in institutional fields: The case of innovation in the dutch concrete industry. Organization Studies, 28 (4), 515-540. http://oss.sagepub.com/content/28/4/515.refs?patientinformlinks=yes\&legid=sposs;28/4/515

Westphal, D. J., \& Zajac, J. E. (2001). Decoupling policy from practice: The case of stock repurchase programs. Administrative Science Quarterly, 46(202), 202-228.1

Westphal, J., Gulati, R., \& Shortell, S. M. (1997). Customization or conformity? An institutional and network perspective on the content and consequences of TQM adoption. Administrative Science Quarterly, 42(2), 366-394. https://www.researchgate.net/ publication/200552327_Customization_or_Conformity_An_Institutional_Perspective_ on_the_Content_and_Consequences_of_TQM_Adoption

Yıldırım, A., \& Şimşek, H. (2011). Sosyal bilimlerde nitel araştırma yöntemleri. (Qualitative research methods in social sciences) Ankara: Seçkin Yayıncılık.

Zajac, E., \& Fiss, C. P. (2006). The symbolic management of strategics change: Sensegiving via framing and decoupling. Academy of Management Journal, 49(6), 1173-1193. 
